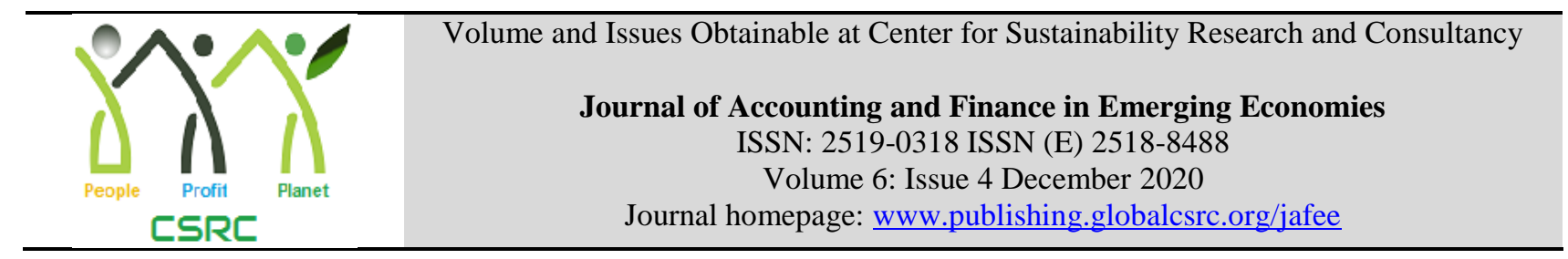

\title{
The Effects of Socio-Cultural Context on Breach of Accounting ethics: A Grounded Theory Study
}

\begin{tabular}{|c|c|}
\hline \multicolumn{2}{|c|}{$\begin{array}{l}\text { 1IIyas Sharif, }{ }^{\mathbf{2}} \text { Muhammad Junaid, }{ }^{3} \text { Shakeel Khan, } \\
{ }^{1} \text { Lecturer, Quaid-e-Azam College of Commerce, University of Peshawar, Pakistan, } \\
\text { ilyasqacc@ } \text { uop.edu.pk } \\
{ }^{2} \text { Assistant Professor, Institute of Management Studies, University of Peshawar, Pakistan } \\
{ }^{3} \text { Lecturer Institute of Management Studies University of Peshawar, Pakistan }\end{array}$} \\
\hline ARTICLE DETAILS & ABSTRACT \\
\hline $\begin{array}{l}\text { History } \\
\text { Revised format: November } \\
2020 \\
\text { Available Online: December } \\
2020 \\
\text { Keywords } \\
\text { Accountants' Behavior, } \\
\text { Accounting Ethics, Social and } \\
\text { Cultural Context, Tax } \\
\text { evasion, loopholes in legal } \\
\text { framework, Promotion of } \\
\text { accounting ethics education } \\
\text { JEL Classification: } \\
\text { M10, M12 }\end{array}$ & $\begin{array}{l}\text { This study explores intuitions of accounting education key } \\
\text { stakeholders in Khyber Pakhtunkhwa, Pakistan that what are the } \\
\text { effects of social and cultural factors on ethical breaches of } \\
\text { accountants and tax evasion. Individual and organizational } \\
\text { decisions are based on accounting yet, social and cultural } \\
\text { obligations coerce accountants on manipulation of accounts for tax } \\
\text { evasion that has negative impact of national exchequer. This study } \\
\text { attempts to realize insights of important stakeholders about AE } \\
\text { through methodical support of its multifaceted angles. Literature } \\
\text { highlights that personal, organizational (multi)national decisions are } \\
\text { based on accounting information. Stakeholders' theory lens is } \\
\text { applied as it is widely used in accounting research. Researchers } \\
\text { have applied qualitative research approach to provoke } 25 \text { open- } \\
\text { ended interviews of respondents like, accounting teachers, students, } \\
\text { professionals, employers, recruiting agencies and their parents. Data } \\
\text { are analyzed through constructivist grounded theory. Findings show } \\
\text { that excessive social demands compel accountants on unethical } \\
\text { accounting practices for tax evasion that is detrimental for the } \\
\text { nation as it makes corruption acceptability in society. In context of } \\
\text { the study, weak academic and HR policies lead to appointment of } \\
\text { less relevant persons for leading accounting seats. } \\
\text { Recommendations of the study are societal interventions, academic } \\
\text { endorsements, regulatory and legislative suggestions for eradication } \\
\text { of ethical breaches by accountants generally and tax avoidance } \\
\text { specifically. }\end{array}$ \\
\hline
\end{tabular}

OPEN ACCESS

(C) 2020 The authors, under a Creative Commons Attribution-

NonCommercial 4.0

Corresponding author's email address: ilyasqacc@uop.edu.pk

Recommended citation: Sharif, I., Junaid, M. \& Khan, S. (2020). The Effects of Socio-Cultural Context on Breach of Accounting ethics: A Grounded Theory Study. Journal of Accounting and Finance in Emerging Economies, 6(4), 1101-1120

\section{Introduction}

Accounting is critical function in organizational sciences which not merely records and disseminates numbers rather also involves interpretation. Accountants may report and interpret institutional 
transactions in multiple forms and ways (Duska, Duska, \& Ragatz, 2011; Klein, 2015; Riccaboni, Giovannoni, Giorgi, \& Moscadelli, 2006). International regulatory bodies of accounting have prescribed a comprehensive set of ethical guidelines along with detailed laws followed around the world. Aims of International Federation of Accountants (IFAC) are to develop, accept and apply global ethical standards for accounting professionals (Cameron \& O'Leary, 2015; Chandler, 2017; Klein, 2015; Mintz, 2014). Members of American Institute of Certified Public Accountants (AICPA) follow its ethical code (Bealman, 2013; Duska et al., 2011; Lawson, Spencer, \& Turek, 2016). Associates of Institute of Chartered Accountants of Pakistan (ICAP) must keep to its Code of Ethics (Hossain \& Nurunnabi, 2011). Nevertheless, globally, misrepresentation in accounting data have been common in public and private sector. Accountants manipulate organizational accounts (Ashraf \& Ghani, 2005; Carmona \& Ezzamel, 2007; Cooper \& Robson, 2006; Low, Davey, \& Hooper, 2008). Thus, accounting professionals bypass ethical boundaries in professional duties which proves disastrous for society.

This does not always cause disasters or immediate damage. Ineffective governance in financial terms may be spotted slowly (Lakshmi, 2018). In fact, most of the times minor or small "manipulation" in accounting record are not easily traceable. Accounting information big users like stock exchange supervisors and professional investors can sense manipulations (Vladu, Amat, \& Cuzdriorean, 2017). Nevertheless, manipulations act like "slow poison" in the long run and can lead to a variety of problems including dwarfed or negative growth or even insolvency. Unethical practices of accountants lead to less human activities and difficulty of reconstruction (Gill, 2012). Firms suffer due to management preference for their own benefit at the cost of institutional good (Burns, Tackett, \& Wolf, 2015; Duska et al., 2011; Rizvi, Tanveer, Saleem, \& Latif, 2012; Roy, 2017; Sikka \& Lehman, 2015; Uyar, Kuzey, Güngörmüs, \& Alas, 2015). Research on causes of misrepresentation in financial data identifies a variety of reasons. Accountants manipulate accounts for own or organizational benefits (Duska et al., 2011; Rebich, 2013; Smith, 2014), due to ignorance (Rebich, 2013), academic dishonesty (Caldwell \& Hayes, 2010; Curtis \& Williams, 2014), lesser audit fee (Ashraf \& Ghani, 2005), tax evasion (Dillard \& Vinnari, 2017; Klein, 2015; West, 2017) and ineffective accounting education (Ken McPhail, 2009). Despite the wide variety of types and reasons of accounting data misrepresentation, it is necessary to understand the real motives and deep-rooted reasons behind them.

\section{Background of the Study}

\subsection{History and Role of Context}

Accounting had actively been practiced since pre-writing Era yet due to social factors conduct of accountants is not uniform. Accounting had existence in Mesopotamian Valley in 3000 B.C. (Alexander, 2002) and Near East in 8000 BC to 3000 BC (Mattessich, 1994). The role of context has been identified as primary factor behind changing nature and magnitude of accounting fraud. Accountants in religious societies avoid deceptions (Dyreng, Mayew, \& Williams, 2012). Confucius in 500 BC opined that rather than coercion rules, best governments use people natural rites and morality (Klein, 2015). Corruption, misconduct and frauds grow where society ignores ethics (Tormo-Carbó, Seguí-Mas, \& Oltra, 2016). Thus, various contextual factors influence conduct of accountants yet, accounting is very integral for any society.

\subsection{General uses of Accounting}

Accounting disseminates monetary details regarding liquidity, profitability, effectivity and turnover level of entire (in)tangible, current and fixed resources of entities. It gathers, records, analyzes, interprets and transfers entity's financial information to its stakeholders (Atrill, McLaney, \& Harvey, 2014; Caliyurt, 2008; Duska et al., 2011; Fea, 1973). Mainly accounting shows organizational monetary results and financial position to various parties for their decisions (Andon, Chong, \& Roebuck, 2010; Coate \& Mitschow, 2015; Earl, 1983; Senate, 1976; Willmott, 1986). Hence, accountants process and disseminate financial details of entities to different interest groups for their decisions.

\subsection{Organizational Internal Use of Accounting}


Accurate, timely, updated accounting figures provide base to organizational decisions and ensure fair, efficient and effective use of owners' wealth by management. Management takes informed organizational decisions based on accounting information (Andon et al., 2010; Earl, 1983; Senate, 1976; Willmott, 1986). Accountancy brings transparency in procurement, usage and bookkeeping of business resources (Andon et al., 2010) and lead to effective functioning of capital market (Palea, 2016) as it reports organizational operational effectiveness and productivity (Coate \& Mitschow, 2015). Since its inception, accounting has been integral for ensuring firms' effective inventory management (Ezzamel, 1997; Stoner, 2011; Yamey, 2000). So, accountants have influential role in organizations where staff and managers rely upon accounting information for quality in their entire decisions still, the same is also valuable for external users.

\subsection{External Users of Accounting}

All relevant individuals and institutions have legal right to receive organizational accounting figures in time, accurately, sufficiently and uniformly. Accountants collect, assess and supply organizational monetary information to owners, financers, creditors, customers, and government agencies (Andon et al., 2010; Earl, 1983; Senate, 1976; Willmott, 1986). However, usually it is not so easy for external users to get accounting information of entities for their multifaceted decisions. Accountants concealed real accounting information from their majority stakeholders (Chabrak \& Craig, 2013; Cordery, 2015; Klein, 2015; Satava, Caldwell, \& Richards, 2006; Sikka, 2009). Even though rewards of all factors of production, public policies and government budgetary decisions are based on accounting information. Various individual, organizational, and government level academic, administrative and managerial decisions are based on accounting (Apostolou, Dorminey, Hassell, \& Watson, 2013; Ashraf \& Ghani, 2005; Haynes, 2017; Parker, 2012; Shahin, 1996). Still, accountants face social pressures due to which they provide late, incomplete or even fake financial information to external stakeholders which is ethically questionable.

\subsection{Practical Situation on Internal Use of Accounting}

To get salary rise, secure jobs, and many (il)legal benefits or oblige some users of accounting information, accountants manipulate accounting records. They (un)willingly maneuver organizational accounts for the benefit of their own or selected organizational stakeholders (Duska et al., 2011; Jones, 2011; Low et al., 2008; Rebich, 2013; Smith, 2014) (Nisha, 2016). Accounting objectively reports financial dealings of entities that lacks neutrality (Riccaboni et al., 2006). Generally accountants mold accounting rules for personal gain and consider it their business insight (Sikka \& Lehman, 2015). Accountants may show exaggerated or devalued organizational results in their reports. They can exhibit exact, inferior or healthier organizational financial position to accounting information users (Duska et al., 2011). Accounting has been used in recording operations and managing power relationships (Riccaboni et al., 2006). Auditors work as extension of firm's management rather than representing and serving external stakeholders (Carnegie \& Napier, 2010). So, accounting professionals usually work for personal gain at the cost of organization or its stakeholders.

\subsection{Practical Situation on External Use of Accounting}

External users perceive accountancy as a magical/fraudulent game as accountants provide accounting and audit services simultaneously. Auditors instead working as watch dogs perform the role of beasts. Accountants do not involve external stakeholders especially in reporting process although their engagement may prove very critical for institutions (Kaur \& Lodhia, 2018). Accountants manipulate organizational accounts for their own and or organizational benefit (Burns et al., 2015; Duska et al., 2011; Rizvi et al., 2012; Roy, 2017; Sikka \& Lehman, 2015; Smith, 2014; Uyar et al., 2015). Accountants take salary for doing nothing and extortion money for processing and providing genuine as well as fake accounting information. Lower management demand extortion or grease money in routine dealings (Alon \& Hageman, 2017; Rosid, Evans, \& Tran-Nam, 2019), it prevails in many countries though, its public perception is not good (Bowie, 1998). So, to safeguard interest of internal users, accountants provide incomplete, blur, or fake accounting information to various stakeholders due to 
various societal pressures.

Social and cultural factors like insufficient income of accountants, tax averse tendency, insecure jobs, acceptability of wealth regardless its legality, ignorance and breaches of ethics compel accountants on crossing ethical boundaries by information hiding, giving late or fake accounting figures. Customer, government regulations, competitors, stakeholders, public and own moral principles determine one's business conduct (Roy, 2017). One adopts unethical conduct when his peers cross ethical limits (Curtis \& Williams, 2014). Same conduct may be (un)acceptable across different societies (Boatright, 2010; Mintz, 2014). Insecure jobs and scarce income of accountants compel them on embezzlements, frauds as they cannot survive in their society without fulfilling community demands. Misusing public office, authority for personal benefit through extortion, bribery, nepotism, fraud, speed money, embezzlement or influence peddling may be termed as corruption (Lukmanjaya, 2019). Accountants' ethical breaches have led to declining public perception about them who consequently do not work for the benefit of many stakeholders (Low et al., 2008). Currently society expects less ethical conduct from businessmen and resultantly business students become less ethical (Smith, 2014; Tormo-Carbó et al., 2016). Thus, due to multifaceted social and cultural demands from accountants compel them on crossing ethical boundaries mainly for tax evasion.

Entire tax mechanism is dependent on accounting where every government plans revenue and expenditure for every fiscal year. Accountants declare tax liability of their employers and ultimately national revenue (Caliyurt \& Crowther, 2006). Government decides various tax rates for different taxpayers based on accounting reports. Individual and organizational taxpayers regularly submit their tax returns along with all supporting accounting records. Accountant hide own, client's and/or employer's taxes by manipulating their respective accounting books. Accountants cross ethical limit in their duties when they lose auditor's independence, and start creative accounting, tax frauds, work for the interest of blue-eyed stakeholders (Jackling, Cooper, Leung, \& Dellaportas, 2007). Sometimes accountants prepare multiple sets of accounts books for tax avoidance. Government revenue is directly dependent on collection of taxes which relies on quality of accounting information of public and private sectors in the economy. Accountants conceal financial information, auditor certify fraudulent accounts to evade taxes lead to default in government revenue targets (Dillard \& Vinnari, 2017; Fu, 1971; Klein, 2015). Auditors as external users of accounting information in the capacity of checkers for tax hiding. Auditors have passed on the bucket of finding frauds to management (Morales \& Sponem, 2017). When tax authorities demand organizational record of revenue and expense, they use the same for calculating their tax liability. Some scholars have termed tax avoidance and tax minimization for deliberate illicit practices (i.e. twisting accounting records) while, tax evasion may be termed as both legal and illegal act, yet scholars and cultures use these terms interchangeably (West, 2017). Although tax fraud is a global issue however, its situation in Pakistan is very alarming especially in indirect taxes (Awan \& Hannan, 2014). Problem of tax evasion exists in Pakistan since 1960, nevertheless, during 1998-2004 its rate was more than 11.4 percent of GDP (Ashraf \& Ghani, 2005). Secret reserves were created to conceal heavy organizational profits earned yet, in unusual cases it should be acknowledged if it relates to benefit of the firm thus, deviating the conflict of interest among various stakeholders (Nisha, 2016).

\subsection{How Ethical Breaches are Motivated for Tax Evasion.}

Accounting professionals breach accounting ethics due to various social and cultural pressures. Accountants mainly commit ethical breaches when they are pressurized to present rosy picture of organizational financial health that has globally led to fraudulent cases like Enron and typo etc. (Adkins $\&$ Radtke, 2004; Satava et al., 2006). Corruption, misconduct and frauds grow in a community where ethics are perceived as an immaterial societal value (Tormo-Carbó et al., 2016). Organizations would not be able to survive where they ignore societal demands (Carnegie \& Napier, 2010; Tsang, 1998). To eliminate unethical accounting practices, strong internal control and external regulatory mechanism are applied. Auditing initiated for higher level of stakeholders' confidence on organizational accounts and giving them exact financial information. For highly credible and reliable accounting records, auditor 
must be independent (Rennie, Kopp, \& Lemon, 2014). For boosting ethical conduct, public should demand that ethical conduct from businessmen (Smith, 2014). Misrepresentation in preparation and audit of accounts may be detrimental for society (Satava et al., 2006). Various audit software for error/fraud detection can prove fruitful (Saud, 2012). Initially, in Pakistan a comprehensive training plan for transfer moral standards from private sector to public sector should be suggested for highly moral practice of accountants (Mujtaba \& Afza, 2011). Religious inclination of individuals decreases their tendency of taking unethical decisions (Zubairu, 2016).

Individuals and organizations cannot survive and grow in isolation of their environment as they simultaneously affect and get affected from their society. Accountancy comprises of three segments practice, research and policy all of which should be intertwined (Guthrie \& Parker, 2016). Unethical conduct of accountants led to scandals and failures of Enron, WorldCom, Tyco, Xerox, Adelphia Communications, Qwest Communications, Bristol-Myers, HIH insurance group in Australia, Global Crossing, Health South, Ahold in The Netherlands, Vivendi-Universal in France and SK Global in South Korea (Low et al., 2008). Growth of materialism in community motivates people for their limitless earning and ignoring of moral obligations. Researchers agree that manipulating accounts can be motivated for benefiting individual(s) and/or the organization (Burns et al., 2015; Duska et al., 2011; Rizvi et al., 2012; Roy, 2017; Sikka \& Lehman, 2015; Smith, 2014; Uyar et al., 2015). Mothers act as the most influential entities in ethical grooming of their children as mother's lap is the first learning seat for any child. Parents, teachers and elders are responsible for unethical conduct of youth (Gill, 2012) People follow instructions of their parents in their individual and professional affairs. They influence carrier choice of their kids (Nikitin, 2001). Accounting educators ignore ethical training of their students and teach their students only in technical avenues of the subject. Contextual factors influence pedagogical approaches due to which business ethics discussion is considered sensitive in Central Asian region (Setó-Pamies \& Papaoikonomou, 2016). Social relations are needed between students and teachers that affect work attitudes and habits (Pan \& Perera, 2012).

Accountants rank monetary interests higher than their ethical duties that has led to numerous ethical tragedies around the globe. Ethical scandals of accountants made the declining public perception as the greatest challenge for the profession (Carnegie \& Napier, 2010). Academic programs generally provide solution to the societal problems however, in accounting education only technical knowledge is focused and ethical training of students is either totally ignored or touched cosmetically. Although university level accounting teachers should provide solution to community problems through their teachings (Kotb, Roberts, \& Stoner, 2013). Role of universities can be influential in eliminating AE breaches (Kotb et al., 2013; Uysal et al., 2010) since learning of ethics is prerequisite for placement of accounting students as officers (Chunhui Liu, Lee J. Yao, \& Hu, 2012). For quality accounting education, accounting professors should enhance critical thinking and thoughts among students through creative curriculum and pedagogies for which connectivity between the social world and accounting topics is required (Chabrak \& Craig, 2013). Accounting students ought understand the relationship of society and business for executing their professional duties ethically (Michaluk, 2011). Thus, to control accounting scandals, academicians should ensure their students ethical grooming because accountancy is the backbone in economic dealings of individuals and organizations.

\section{Theoretical Framework}

Teleological viewpoint does not allow firms to commit social evils (Boatright, 2010). For unified business ethics, integrative social contract theory was pioneered where normative judgement is performed through combining empirical results as a part of contractarian procedure (Ma, 2009). The theory emphasizes on expressed or implied understanding among groups and persons for the suitable division and use of property (Donaldson \& Preston, 1995). Researchers in studies of moral conduct of businesses and their managers have extensively used the framework of social contract theory (Boatright, 2010; Carnegie \& Napier, 2010; Dempsey, 2013; Donaldson \& Preston, 1995; Ken McPhail, 2009; Lakshmi, 2018; Ma, 2009; Smith, 2014; West, 2017; Williams \& Adams, 2013). Despite its effectivity 
in conceptualizing the relationship among members of society, legally enforceable status is the lacking of this theory (West, 2017). This theory considers that organizations will be legitimate and survive when they are run in wider societal values (Williams \& Adams, 2013; Carnegie \& Napier, 2010). General insight in a community that ethics is an irrelevant social value, led to freedom that caused fraud, corruption and interactive misconducts of public sector top level management (Tormo-Carbó et al., 2016). Accounting teachers should work on curriculum and pedagogies for inculcating critical thoughts in students for which connection between social world and accounting topics is needed (Chabrak \& Craig, 2013).

\section{Scope of the Study}

This study attempts to comprehend empirically social and cultural dimension of AE breaches in Pakistan. For quality education of accounting ethics researchers should examine cultural and regulatory facets (Marzuki, Subramaniam, Cooper, \& Dellaportas, 2017). No study in Pakistan has been conducted on corporate social reporting (Yunis, Durrani, \& Khan, 2017). Hence, this study will explore social and cultural reasons for accountants' breaches of AE which result in tax evasion.

\section{Research Methodology}

\subsection{Qualitative Research Methods}

This study gears qualitative research method to empirically grasp the socio-cultural facets for accountants' crossing ethical limits in their professional duties. Inductive research methods effectively measure and identify concepts relating to perceptions of situations and selves (Eisenhardt, Graebner, \& Sonenshein, 2016). To study complex human actions and management concepts, qualitative methods of research are required for research in management sciences (Lehnert, Craft, Singh, \& Park, 2016; Point, Fendt, \& Jonsen, 2017). Qualitative research methodology is opted due to its suitability to the subject area generally and topic specifically. Qualitative data are suitable for examining phenomena that are not properly comprehended (Edmondson \& McManus, 2007). More use of qualitative research methods for business ethics research is suggested (Campbell \& Cowton, 2015). Qualitative research methods permit thorough exploration of how people observe and tackle the dilemmas that they face (Treviño, den Nieuwenboer, Kreiner, \& Bishop, 2014). Thus, considering exploratory nature of the study, its requirements and recommendations from literature, researchers chose qualitative research methods where opting of grounded theory looks most appropriate.

\subsection{Grounded Theory}

Grounded theory methods have been widely used or have high potential for analyzing ethical questions on individual, organizational, or societal levels (Heugens \& Scherer, 2010). Through grounded theory scholars universally comprehend social creations of research participants while, among the modern qualitative methods, GT is perceived to be the most vital and positivist (Kathy Charmaz, 2008). Researchers from numerous disciplines opt for GT due to its more explanatory power and higher degree of dependability for interpretive studies (Camic, Rhodes, \& Yardley, 2003). Researchers in social science most widely use GT (Buckley \& Waring, 2013, ; Langley, 1999);. Hence, as a highly reliable qualitative approach for research in the discipline of accountancy, researchers opted for GT for which suitable sampling procedure must be applied to achieve research objectives of the study.

\subsection{Sampling Procedures}

Researchers of the study categorized, accounting education's important stakeholders into teachers, students, professionals, recruiting agencies, employers and their parents out of which 25 educated, keen and available people were selected. Researchers purposively select respondents because of their understanding of the subject matter (Creswell, 2013; Hughes, 2010). To control scandals, ethical grooming needs multifaceted views, spirits and behaviors about values that direct people what they should do (Mpho, 2017). In GT, process of theory generation is inductive and iterative where growing insights govern inclusions and selection of the next chunk of data or information, by theoretical sampling (Gephart, 2004; Treviño et al., 2014). In GT, sample does not represent population rather it is 
selected for theory generation (Hoque, Parker, Covaleski, \& Haynes, 2017). Consequently, the sample selected is highly appropriate and pertinent where instead conducting the study in a straight line, iterative ways were used.

\subsection{Interviewing}

Constructivist GT researchers have flexibility and start data collection before finalizing theoretical framework, where they jointly generate data with their participants. In GT studies data collection starts without any prior theoretical framework, because here theory generates out of the data collected (Saunders, 2011). Because of constructivist GT's reflexivity and relativeness, scholars and their interviewees co-construct data (Bryant \& Charmaz, 2007). Due to flexibility in GT analytic methods, researchers collect data and construct middle-range inductive theories through successive data analysis phases (Kathy Charmaz, 2005). Thus, to co-construct data and generate theory, researcher interviewed 25 respondents whose discussion was properly audio recorded.

To focus on questioning and collect data from respondents, interviews were audio recorded. Audio recording of interviews ensures thorough analysis of the fresh collected data (O'Leary, 2004). Audio recording of pre-organized respondents' interviews and proper note-taking raise credibility of data (Hoque et al., 2017). Researcher applied note taking for interviews where either voice recording was not possible or allowed (Hoque et al., 2017; Sengupta \& Sahay, 2018). To ensure rigorous research, verbatim transcription of interviews was applied (Cowton \& Downs, 2015). Saturation is the point where no new concepts arise rather classes and their relationships are sufficiently grounded and confirmed (Dai \& Free, 2016; Green \& Thorogood, 2013; Lu, 2010). Consequently, data collection through participants interviews continued till saturation where collected data were analyzed accordingly.

\section{Data Analysis}

\subsection{Coding Procedures of Grounded Theory}

Manual coding was applied on chunk by chunk basis where data were parallelly collected and analyzed which was hard process as researchers decomposed, abstracted and reorganized data through coding. To organize and code data, qualitative software may be used, though, they are not good choice for data interpretation (Suddaby, 2006). Concurrent data collection and analysis saves researchers from gathering general, rubbish and blurred data and ensure optimum use of their energies (K Charmaz, 1995). Code is a tag given to a certain text to show its meaningfulness for the study while coding differentiates pieces of text to identify, shape and interpret its key characteristics (Hughes, 2010). By using careful readthoughts of data and line by line coding, certain examples of ordering in the data were identified (Pine \& Mazmanian, 2016). GT has certain hard to control downsides yet, it brings consistency in qualitative researches (Hoque et al., 2017). Scholars using GT, decompose, abstract, reorganize data in novel ways (Bhal \& Leekha, 2008). Thus, to control problems in GT data were gathered and analyzed parallelly where manual chunk by chunk coding was practiced for every meaningful thought to decompose, abstract and rearrange data in innovative ways for which various versions of coding were available.

Although GT researchers used disagreed over the naming of codes yet, its data analysis comprises of six steps where data is described and compared. Initially, Strauss and Corbin termed codes as open, axial and selective codes whereas, Charmaz labeled them respectively as initial, focused and theoretical codes (Cho \& Lee, 2014). GT researchers analyze data by using open, axial and selective codes (Bhal \& Leekha, 2008). GT analysis completes in six stages: Open coding, extracting categories, evolving themes, examining the themes linking the facts and theory separation (Cho \& Lee, 2014; Harry, Sturges, \& Klingner, 2005). Codes explain nature of data nature through description (K Charmaz, 1995). In axial coding researchers seek similarities and differences among the categories that finally reduces the number of categories to a manageable figure (Gioia, Corley, \& Hamilton, 2013; Hay \& SamraFredericks, 2018). So, because of the available analytic freedom of data, researcher opted for Charmaz's constructivist version of GT which led to concluding findings of the study. 


\section{Findings}

\subsection{Accountants Face Ethical Problems}

Findings that emerged in this theme exhibit that organizational culture is in the way of proper implementation of accounting ethics. Accountants cross ethical boundaries in execution of their professional duties for avoiding tax due to weak regulatory bodies. Officials commit breach of $\mathrm{AE}$ because of ignorance from rules and regulation.

Table 6.1 Theme

\begin{tabular}{cc}
\hline Theme Categories & \\
\hline $\begin{array}{c}\text { Ignorance and Unfriendly Organizational Culture Promote AE Breaches for Evading Taxes } \\
1 \\
2 \\
3\end{array}$ \\
Organizational culture as barrier to AE \\
Ignorance from Rules and Regulations
\end{tabular}

Source: Author

\subsection{Organizational Culture as Barrier to AE}

Findings of this category show that causes of corruption are deep rooted in culture of the context where people accept and feel pride of being expert in corruption. In Khyber Pakhtunkhwa people may be easily persuaded for breaches of accounting ethics where they get its monetary benefit to pay their socially needed expenditures.

Defining corruption as a habit of stealing something even a little time as duty from the organization. Corruption inherits from seniors to juniors. Absenteeism of staff from their workplace during duty hours is one of the top five most prevalent reported corrupt practices across organizations (Onwujekwe et al., 2019). Widespread social insight that accounting ethics are irrelevant societal value, brings freedom usually followed by bribery, embezzlement and interactive misconducts among public officers (TormoCarbó et al., 2016). Internal auditors report suspected frauds, bribery, and misappropriations that assists in following regulatory directives and accurate reporting (Klein, 2015). Thus, rejection of ethics as a social value leads to staff's corruption in their duty timing and financial terms for which strong control mechanism and whistleblowing by auditors are needed

... every person is involved [in corruption] ranging from lower level to higher level. (R3, L. 259) ... I use to do corruption (in duty timing). (R3, L. 265) ... this [habit of teachers' theft in duty hours] will transfer to me. (R3, L270).

... in our society ... corruption is done by everyone ... where everyone has his share. (R5, L 108)

Socio-cultural environment has multidimensional effect in promoting or controlling embezzlement. The acceptability of corruption as a common practice does not allow individuals to follow organizational rules and regulations in silos. They are hard pressed to accept the common culture rather than living in a cocoon.

... reasons of corruption can be personal issues, domestic problems, personal lust and desires (R5, L.112)

... a minister ... told in a live interview "Corruption has become so common, where we have also the right to take our share”. (R5, L.106)

... problem is that ... employees do corruption ... and expect ... that others will pay tax. (R5, L109) ... If a person [accountant] is unaware of the difference of right and wrong, ... that person will process wrong cases. (R12, L. 241)

Pashtun culture and its requirements compel individuals to spend beyond earnings and find any illegal 
avenues to fulfill their needs. Moral rules variate over time, across cultures, religions and political structures (Klein, 2015; Young, 2013). Business ethics in Western society mainly developed from spiritual values that recognized as organizational regulations for running and controlling activities of businessmen (Zhu \& Zhu, 2016). For ethical conduct of professionals society must improve collective views, manners and feeling about ethics (Mpho, 2017). Spanish In accounting education main emphasis was on technical aspects where the desire of linking them to the actual world generally and social world specifically was missing (Carmona, 2013). Considering rise in corporate scandals McPhail recommended inculcation of ethics in management curriculum (Carmona, 2013). A comprehensive training plan is recommended for more ethical practice where moral values will transmit to public sector from private sector in Pakistan (Mujtaba \& Afza, 2011). Hence, global disagreement over moral rules and relaxing values declined morals, beliefs and lifestyles in Pashtun culture where accountants start embezzlement to earn beyond legal means for fulfilling their societal obligations.

... corruption is ... started from some compulsion ... from customs and ... environment. (R16, L78) ... we invest in home in the form of buildings, cloths and we feel the difference in our cloths, weddings, educational expenditures and in medication or treatment and the expenditure of our family relationship. $(R 16, L .81)$

Society's indifferent behavior to wealth earned through corruption in culture and society of Pashtuns. Less societal focus on moral values led to unethical conduct of accountants that legitimized and triggered embezzlement. Slow moment of ethics from absolute to relative footings caused unethical conduct of accountants (Young, 2013). It is illogical to teach moral values, critical thinking and relativism to students in their accounting classes whereas in finance and management modules they are taught shareholders' wealth maximization (Carmona, 2013). Corruption exists predominantly in Pakistan, India and Bangladesh due to multifaceted political and economic connections between patrons and clients (Azmat \& Samaratunge, 2009). International literature highlights that weaknesses in accounting education and the active role of accountants promoted their capitalist mindset that has led to the existing alarming status of information hiding from stakeholders. Shareholder theory considers stockholders wealth maximization as the only legal and moral obligation of firm management (Klein, 2015). Controversy exists among researchers for the last century on the point whether capitalism is (im)moral; nevertheless, the role of accounting has regularly been influential for capitalism (Low et al., 2008). In stock market-based capitalism those firms remain effective who hide accounting information from their stakeholders (Walker, 2010). Almost fifty years ago, Pakistan was an exemplary nation however, this pace was lost due to unethical conduct of accountants. Despite statutory requirement of implementing accounting standards in Pakistan, such mandatory compliance is not constantly ensured (Hossain \& Nurunnabi, 2011). Pakistani corporate sector has not internalized corporate social responsibility rather some external factors generally enforce CSR upon them (Yunis et al., 2017). During 1957-68 Pakistan emerged as the most remarkable case of nation and state building since World War II however, due to lack of social justice, pace of the economic growth could not retained (Ashraf \& Ghani, 2005). Thus, the trend of society to respect wealth rather than characters gives courage to accountants for frauds.

If everyone is telling him that there should be money and respect belongs to money ... he will concentrate on money and ... he will forget honesty trustworthiness and fairness. (R30, L. 235)

... Now, the point of wealth's legitimacy or illegitimacy is side lined and those persons who have more money are acceptable to society and given value. (R9, L. 133).

Environment role models like parents, household and peer pressure shape one's personality regarding response to corruption. Parents, teachers, social interactive customs and superiors have decisive influence on accountants (un)ethical professional choices (Adkins \& Radtke, 2004; Gill, 2012; Melé, 2005; Jackling \& Keneley, 2009). Individuals' personal virtues have very less or no influence on their conduct when they face pressure from their peers (Caldwell, 2010; Chandler, 2017; McGuire, Omer, \& 
Sharp, 2012; Solomon, 2003). World flourishes when people follow collective ethical and cultural principles (Klein, 2015). Accounting educators should promote critical rational in students, bring creativity in curricula and pedagogies for which they should link accounting with social world (Chabrak \& Craig, 2013). Associates of the American Institute of Certified Public Accountants (AICPA) enthusiastically accept the duty of ethical and professional conduct (Bealman, 2013). Pakistani corporate sector and researchers have overlooked CSR activities (Yunis et al., 2017). Hence, parents, teachers, family members, colleagues and colleagues should indoctrinate ethical awareness and sensitivity among accountants that will bring justice and curb corruption in society.

... corruption is a mindset and it is quite common practice in our society that since childhood a person is corrupt. ... In it first is person's home environment, next ... when a person goes to school, college and university, there is also the same environment in various forms. (R12, L. 128)

Ethics as a subject should properly be included in curriculum of colleges and universities ... many such courses are taught, which are totally irrelevant to our [accounting] subject. (R11, L448).

... everyone must know about his responsibility either it is on school level, college level, university level and then he should share information with honesty to achieve good results. (R15, L165).

Scarce nurture, defective education and unconducive organizational environment legitimize illegal incomes. Everyone knows that all members of society call for their legitimate part in corruption.

\subsection{AE Breaches for Tax Evasion}

In this category it is emerged through analysis of the respondents interviews that accountants in many roles assist in tax evasion by manipulating accounts. Tax evasion is disastrous for every nation. Defective tax regulatory system and desire for money are the causes of tax evasion which can be controlled through academic and regulatory remedies.

Participants of the study narrated many actors in and reasons of tax evasion. Accountants breach professional ethical boundaries for evading taxes. Accountants manipulate organizational accounts for tax evasion (Klein, 2015; West, 2017) while audit firms assist in evading taxes of their clients (Lakshmi, 2018). Taxes are avoided in all societies where taxes are imposed on public and even Babylonians society witnessed tax evasion (Klein, 2015). Due to insecure job structure accountants are compelled to manipulate firms' accounts for evading taxes. CAs parallel services of preparing and auditing their clients' accounts for tax hiding. Tax policy having high tax rates, no advantage for taxpayers, undocumented economy, distrust of tax authorities on tax returns of (un)fair firms, unproductive employees of regulatory system result in black money and tax evasion that is detrimental for exchequer. Russia is on the top of the list in evading taxes (Shawver \& Miller, 2017). It is high time for accounting researchers to pressurize policy makers for designing of effective and efficient policies (Palea, 2016).

Every person registers himself online ... receive online notice or email for submitting his return. ... he will declare all his bank accounts and their deposits and withdrawals, income, expenditure etc. He would not be able to do tax evasion. (R12, L288)

... CA firms are built for the for purpose to assist people in tax evasion. (R11, L. 249)

... they [CAs] aid with tax evasion ... this is a very great disservice to the profession. $(R 14, L 8)$

Tax avoidance should be viewed as a crime ... be justified to people that why they should pay tax. (RI1,

L. 174)

... the largest medicine distribution of Peshawar ... maintain two types of books of accounts: one for themselves and their partners and the other of public and tax. (R11, L.478). ... where they avoid everything, also get tax benefit and show to public that they ... work with nominal service passion. (R11, L.481) ... there was a difference of almost Rs. 40 billion in profit of both sets of books. $(R 11, L .485)$... it was legal money but they had transferred it to robbery due to tax avoidance. $(R 11, L .487)$ ... the tax payment culture in Pakistan is very weak; people do not pay taxes. From ... government. employees, their taxes are deducted, while most of the business class people do not pay their taxes. (R13, 


\section{L.90)}

... by nature humans are greedy and want to maximize their profit ... it [tax] must be spent by state on tax payers ... in Pakistan ... people do not get facilities due to which people are not willing to pay tax ... their taxes are not properly utilized. (R13, L.97)

... basic duties of state like: health, education, infrastructure, law and order situation are if focused and provided to public then people will pay taxes. (R13, L. 107)

... It is needed that current resources be utilized properly; ... If public is not given something, then how they will pay taxes? (R13, L. 114)

The main reason for that [duplication of accounts books] is tax evasion. (R.30, L. 166).

Taxes are mostly avoided for money saving. (R29, L65).

Most of the citizens of this country are low salaried and receive less facilities while, they want high living standards that's why people do corruption. (R26, L. 48)

... People pay taxes to government for financing infrastructure, roads, health facilities, ensuring law and order situation and political stability ... neither complete infrastructure, nor health facilities are uniformly given to public and people hire private guards for their safety. (R29, L65).

Why NAB and this like departments are introduced because the people are not sincere and not reporting the actual values. (R.16, L.65).

Similarly, NAB investigates corruption cases based on accounting information. (R.13, L. 62).

... either during the planning process when they have set these goals, they have committed mistakes, or based on their planning grounds, by default there is some deficiency or weakness in the data or secondly that can be pragmatic or unrealistic, I think these can be its main reasons that unrealistic goals are determined (R4, L. 329)

The problem of black money prevails due to AE breaches here [reporting function of accounting]. (R3, L84). Economy will go down, if tax will not be collected properly. (R3, L405)

The participants came up with many valuable recommendations for controlling evasion of taxes since, currently only salaried class pay taxes. Tax system can only improve if bribery is eliminated among FBR staff. Government should ensure firms' registration and documentation of overall economy for making tax evasion impossible. Curricula of accounting programs should be enriched with AE. Judicial inefficiencies, weak law enforcement and lack of investor protection can better explain financial reporting practices in Pakistan (Ashraf \& Ghani, 2005). Government should ensure transparent collection disbursement of taxes through effective internal control and strict regulations for taxation. For tax fairness and controlling of tax evasion it should be obligatory for companies to adapt standardized accounting plan (Caria \& Rodrigues, 2014).

... sometimes we link manager promotion or perks to the output which if not legally feasible within the legal framework because, humanly or due to lack of ethical education in accounting, it is a natural fact that most of the accountants will go towards unethical issues. (R4, L337) ... Then definitely tendency and aptitude towards unethical practices raise. (R4, L. 355)

System (of FBR) is not functional properly because of corruption. (R26, L. 45)

All salaried persons pay taxes as it is withheld from their salaries. (R.30, L.58).

Tax is not collected fairly from all persons because taxes are deducted from salaried persons while business sector avoid taxes with whom FBR staff has setting.(R12, L276)

... industrialists avoid taxes through FBR employees and due to faulty tax system. (R29, L70).

The registered people pay the tax and non-registered people do not pay the tax. $(R 33, L 42)$. 
Tax system should be made transparent by keeping a check of FBR employees. (R29, L77).

Tax law should be simplified so that tax payers may personally file returns. (R29, L78).

... The government should facilitate the tax collectors and take some hard actions to insure tax collection. (R33, L47).

Unethical accountants, defective laws and their discriminatory application and lack of benefit of taxes for taxpayers results in tax evasion. Tax evasion will exist till eradication of corruption among FBR staff. Working on academia and lawmaking can also help in controlling tax evasion.

\subsection{Ignorance from Rules and Regulations}

In this category emerging findings show that officials unknowingly ask accountants for unethical accounting practices. Mindfulness of AE influences conduct of accountants. Current university level accounting education in the context of the study has many weaknesses.

Respondents of the study linked unethical accounting practices ignorance and narrated on its reasons and academic solutions. Existence of corruption show failure of (in)formal institutions of ethical education (Sikka \& Lehman, 2015). Executives and accountants ignorantly breach AE while, persons aware of AE do not bypass AE. Professionally and ethically university accounting graduates are quite weak for which incorporation of $\mathrm{AE}$ in curriculum is suggested. Ineffective accounting education results in ethical breaches for tax evasion (Ken McPhail, 2009).

... society should be educated about the consequences of not following ethics ... For this both public and private institutions will have to take stand. (R.11, L. 236).

... CSS is such an exam whose CSPs mostly come to our [accountancy] cadre though, a bit irrelevant. (R2, L152). When these persons upon successful Commission or CSS exam join our department as officers, they even do not know what to do? (R2, L159).

... he [poor] cannot get education and uneducated persons have ethical problems. (R27, L 51).

Accountant aware of $A E$... will, abide by AE otherwise he will give loss to owner. (R21, L112).

... The government should aware, check and force the people about tax payment. (R33, L42).

\section{Conclusion}

In answer to the research question researchers found that pride of people on $\mathrm{AE}$ breaches have legitimized bypassing accounting practices. Weak regulatory system, flawed organizational targets and structure trigger greed among accountants who consequently breach AE. Illiteracy of AE leads to weak regulations that resultantly increase manipulation of accounts among accountants. To hide heavy profits earned from wars, undisclosed funds were created nevertheless, it should be recognized in emergency if it is beneficial for business (Nisha, 2016). Thus, ignorance of AE encourages its breaches that has multifaceted repercussions for countless stakeholders in a society.

Ignorance of AE influences societal aspects, performance of regulatory system, unfair HR policies and weak regulations where accountants easily breach $\mathrm{AE}$ (un)willingly. Unethical accounting practices weaken regulatory mechanism and encourage bribery among accountants. Accountants in their multifaceted roles support evasion of personal and organizational taxes. Accounting professionals sacrifice their ease and owners' heavy investment on electronic accounting system because of higher degree of transparency that is unethical. AE breaches decrease efficiency of accounting professionals, their stakeholders which is disastrous at micro and macro levels.

\section{Recommendations}

Commendations of the study may be categorized into four sections. Valued, practicable and realistic 
social involvements are recommended. Numerous academic suggestions are given for uplifting teaching and training of accountants. Operative regulatory suggestions are endorsed for accounting professionals who disseminate financial information for decision making to all stakeholders. Finally, legislative suggestions are given for controlling ethical breaches by accountants generally and tax evasion especially.

\subsection{Societal Level Interventions}

Societal role models like parents, teachers, family and peer groups should ensure upbringing of accounting students and professionals by indoctrinating moral awareness and sensitivity through practical implementation of ethics in their own lives.

Staff corruption in duty timing and financial terms can control through acceptance of ethics as a social value and avoiding indifferent behavior of people to (il)legal earnings (with)out corruption. High focus of Pashtun society on moral values will eradicate embezzlement through its illegitimacy. There should be unity among various societies over ethical rules. Simplicity, beliefs and morals should be decisive societal rules and strictly followed.

\subsection{Academic Endorsements}

For elimination of accountants' information hiding and capitalist mindset, effective working on existing problems of accounting education like weaknesses in curricula, delivery and examination system are suggested. Accounting academicians must enrich curricula with accounting ethics and teach the same to their students who will resultantly adopt ethical conduct in their prospective professional roles. Accounting graduates should be professionally and ethically trained otherwise they will (un)knowingly breach accounting ethics.

\subsection{Regulatory Suggestions}

Regulations should be updated for restraining accountants from breaching accounting ethics. For elimination of corruption regulations should be strengthened through effective control mechanism and whistleblowing auditors. For higher national economic growth ethical conduct of accountants in their multifaceted roles should be ensured. For eradication of unlawful earnings working environment for accountants should conducive for implementation of their legal and ethical duties. Registration of all businesses and elimination of bribing practices are recommended for implementation of taxes.

\subsection{Statutory Suggestions}

Reforms in tax laws are recommended for elimination of tax evasion. Realistic tax policy, reasonable tax rates and benefits of taxes for taxpayers, economy's documentation, FBR staff's dutifulness and considering firms' returns filed to regulatory bodies are suggested for elimination of black money and tax evasion that will consequently improve national exchequer. Government should ensure legislation and uniform implementation of law for fair collection and disbursement of taxes. Overall HR policies across the nation should be revised where appointment and promotion of right and relevant person is ensured in all organizations.

\section{Future Research Directions}

Future researchers should focus on curriculum of accounting programs at university level to understand whether accounting teachers ensure its delivery in the effective way or not and advise possible improvements in curriculum as well as its delivery to students. Similarly, potential researchers should examine teachers' training programs for coaching newly developed curricula. Comprehensive studies on religious aspects in training and practice of accounting generally and AE specifically may prove very productive. Prospective scholars should study the role of dominant stakeholders like universities in education of AE. Future research is endorsed for finding effective ways of computerizing manual system of accounting and finance. Researchers in the area may quantitatively test results of the study. 


\section{References}

Adkins, Nell, \& Radtke, Robin R. (2004). Students' and Faculty Members' Perceptions of the Importance of Business Ethics and Accounting Ethics Education: Is There an Expectations Gap? Journal of Business Ethics, 51(3), 279-300.

Alon, Anna, \& Hageman, Amy M. (2017). An institutional perspective on corruption in transition economies. Corporate Governance: An International Review, 25(3), 155-166.

Andon, Paul, Chong, Kar Ming, \& Roebuck, Peter. (2010). Personality preferences of accounting and non-accounting graduates seeking to enter the accounting profession. Critical Perspectives on Accounting, 21(4), 253-265. doi: http://dx.doi.org/10.1016/j.cpa.2010.01.001

Apostolou, Barbara, Dorminey, Jack W., Hassell, John M., \& Watson, Stephanie F. (2013). Accounting education literature review (2010-2012). Journal of Accounting Education, 31(2), 107-161. doi: http://dx.doi.org/10.1016/j.jaccedu.2013.03.001

Ashraf, Junaid, \& Ghani, WaQar I. (2005). Accounting development in Pakistan. The International Journal of Accounting, 40(2), 175-201.

Atrill, Peter, McLaney, Eddie, \& Harvey, David. (2014). Accounting: An Introduction, 6/E (Vol. 6): Pearson Higher Education AU.

Awan, Abdul Ghafoor, \& Hannan, Abdul. (2014). The Determinants of Tax Evasion in Pakistan: a CaseStudy of Southern Punjab. International Journal of Development and Economic Sustainability, 2(4), 50-69.

Azmat, Fara, \& Samaratunge, Ramanie. (2009). Responsible Entrepreneurship in Developing Countries: Understanding the Realities and Complexities. Journal of Business Ethics, 90(3), 437-452.

Bealman, Vicki Donna. (2013). Certified Public Accountant Education and Ethical Decision-Making Preparedness: A Phenomenological Study Exploring the Connection. Liberty University.

Bhal, Kanika Tandon, \& Leekha, Nivedita D. (2008). Exploring cognitive moral logics using grounded theory: The case of software piracy. Journal of Business Ethics, 81(3), 635-646.

Boatright, John R. (2010). Finance ethics: Critical issues in theory and practice (Vol. 11): John Wiley \& Sons.

Bowie, Norman E. (1998). A Kantian theory of capitalism. Business Ethics Quarterly, 37-60.

Bryant, Antony, \& Charmaz, Kathy. (2007). The Sage handbook of grounded theory: Sage.

Buckley, Charles A, \& Waring, Michael J. (2013). Using diagrams to support the research process: Examples from grounded theory. Qualitative Research, 13(2), 148-172.

Burns, David J, Tackett, James A, \& Wolf, Fran. (2015). The Effectiveness of Instruction in Accounting Ethics Education: Another Look Research on Professional Responsibility and Ethics in Accounting (pp. 149-180): Emerald Group Publishing Limited.

Caldwell, Cam. (2010). A ten-step model for academic integrity: A positive approach for business schools. Journal of Business Ethics, 92(1), 1-13.

Caldwell, Cam, \& Hayes, Linda A. (2010). Leadership, trustworthiness, and ethical stewardship. Journal of Business Ethics, 96(4), 497-512.

Caliyurt, Kiymet Tunca. (2008). CHAPTER ONE ACCOUNTING ETHICS EDUCATION: IS THERE A DIFFERENCE BETWEEN DEVELOPED AND DEVELOPING COUNTRIES? Globalization and Social Responsibility, 1.

Caliyurt, Kiymet Tunca, \& Crowther, David. (2006). The Necessity of Fraud Education for Accounting Students: A Research Study From Turkey. Social Responsibility Journal, 2(3/4), 321-327. doi: doi:10.1108/17471117200600009

Cameron, Robyn Ann, \& O'Leary, Conor. (2015). Improving Ethical Attitudes or Simply Teaching Ethical Codes? The Reality of Accounting Ethics Education. Accounting Education, 24(4), 275290. doi: 10.1080/09639284.2015.1036893

Camic, Paul M, Rhodes, Jean E, \& Yardley, Lucy Ed. (2003). Qualitative research in psychology: Expanding perspectives in methodology and design: American Psychological Association.

Campbell, David, \& Cowton, Christopher J. (2015). Method issues in business ethics research: Finding credible answers to questions that matter. Business Ethics: A European Review, 24(S1).

Caria, Ana Alexandra, \& Rodrigues, Lúcia Lima. (2014). The evolution of financial accounting in 
Portugal since the 1960s: A new institutional economics perspective. Accounting History, 19(12), 227-254. doi: 10.1177/1032373213511319

Carmona, Salvador. (2013). Accounting curriculum reform? The devil is in the detail. Critical Perspectives on Accounting, 24(2), 113-119. doi: http://dx.doi.org/10.1016/j.cpa.2012.03.004

Carmona, Salvador, \& Ezzamel, Mahmoud. (2007). Accounting and accountability in ancient civilizations: Mesopotamia and ancient Egypt. Accounting, Auditing \& Accountability Journal, 20(2), 177-209.

Carnegie, Garry D, \& Napier, Christopher J. (2010). Traditional accountants and business professionals: Portraying the accounting profession after Enron. Accounting, Organizations and Society, 35(3), 360-376.

Chabrak, Nihel, \& Craig, Russell. (2013). Student imaginings, cognitive dissonance and critical thinking. Critical Perspectives on Accounting, 24(2), 91-104.

Chandler, Roy A. (2017). Questions of ethics and etiquette in the Society of Accountants in Edinburgh, 1853-1951. Accounting History, O(0), 1032373216675912. doi: doi:10.1177/1032373216675912

Charmaz, K. (1995). Grounded theory. I: JA Smith, R. Harré \& L. Van Langenhove (red): Rethinking methods in psychology (s. 27-49): London: Sage.

Charmaz, Kathy. (2005). „Grounded theory in the 21st century: A qualitative method for advancing social justice research." S. 507-535 w Handbook of Qualitative Research, red. N. Denzin i Y. Lincoln: London: Sage.

Charmaz, Kathy. (2008). Constructionism and the grounded theory method. Handbook of constructionist research, 397-412.

Cho, Ji Young, \& Lee, Eun-Hee. (2014). Reducing confusion about grounded theory and qualitative content analysis: Similarities and differences. The qualitative report, 19(32), 1-20.

Chunhui Liu, Lee J. Yao, \& Hu, Nan. (2012). Improving Ethics Education in Accounting: Lessons from Medicine and Law. Issues in Accounting Education, 27(3), 671-690. doi: 10.2308/iace-50150

Coate, Charles J, \& Mitschow, Mark C. (2015). Benefit corporations as a socially responsible business model: The role of accounting. Research on Professional Responsibility and Ethics in Accounting, 19, 129-147.

Cooper, David J, \& Robson, Keith. (2006). Accounting, professions and regulation: Locating the sites of professionalization. Accounting, Organizations and Society, 31(4), 415-444.

Cordery, Carolyn. (2015). Accounting history and religion: A review of studies and a research agenda. Accounting History, 20(4), 430-463.

Cowton, Christopher J, \& Downs, Yvonne. (2015). Use of focus groups in business ethics research: potential, problems and paths to progress. Business Ethics: A European Review, 24(S1).

Creswell, John W. (2013). Research design: Qualitative, quantitative, and mixed methods approaches: Sage publications.

Curtis, Mary B, \& Williams, John M. (2014). The Impact of Culture and Training on Code of Conduct Effectiveness: Reporting of Observed Unethical Behavior. Research on Professional Responsibility and Ethics in Accounting (Research on Professional Responsibility and Ethics in Accounting, Volume 18) Emerald Group Publishing Limited, 18, 1-31.

Dai, Narisa Tianjing, \& Free, Clinton. (2016). Interview-Based Research in Accounting 2000-2014: A Review. Available at SSRN 2711022.

Dempsey, James A. (2013). Business ethics \& collective responsibility. University of St Andrews.

Dillard, Jesse, \& Vinnari, Eija. (2017). A case study of critique: Critical perspectives on critical accounting. Critical Perspectives on Accounting, 43, 88-109. doi: https://doi.org/10.1016/j.cpa.2016.09.004

Donaldson, Thomas, \& Preston, Lee E. (1995). The stakeholder theory of the corporation: Concepts, evidence, and implications. Academy of management Review, 20(1), 65-91.

Duska, Ronald, Duska, Brenda Shay, \& Ragatz, Julie Anne. (2011). Accounting ethics: John Wiley \& Sons.

Dyreng, Scott D, Mayew, William J, \& Williams, Christopher D. (2012). Religious social norms and corporate financial reporting. Journal of Business Finance \& Accounting, 39(7-8), 845-875. 
Earl, M. (1983). Accounting and Management in Earl MJ,(Ed) Perspectives in Management: Oxford University Press.

Edmondson, Amy C, \& McManus, Stacy E. (2007). Methodological fit in management field research. Academy of management review, 32(4), 1246-1264.

Eisenhardt, Kathleen M, Graebner, Melissa E, \& Sonenshein, Scott. (2016). Grand Challenges and Inductive Methods: Rigor without Rigor Mortis. Academy of Management Journal, 59(4), 11131123.

Ezzamel, Mahmoud. (1997). Accounting, control and accountability: preliminary evidence from Ancient Egypt. Critical Perspectives on Accounting, 8(6), 563-601.

Fea, W. W. (1973). The Accountant-Overhead Burden or Service? Proceedings of the Institution of Mechanical Engineers, 187(1), 687-697. doi: 10.1243/pime_proc_1973_187_061_02

Fu, Philip. (1971). Governmental accounting in China during the Chou Dynasty (1122 BC-256 BC). Journal of Accounting Research, 40-51.

Gephart, Robert P. (2004). Qualitative research and the Academy of Management Journal. Academy of Management Journal, 47(4), 454-462.

Gill, Lesley. (2012). Systemic action research for ethics students: curbing unethical business behaviour by addressing core values in next generation corporates. Systemic Practice and Action Research, 25(5), 371-391.

Gioia, Dennis A, Corley, Kevin G, \& Hamilton, Aimee L. (2013). Seeking qualitative rigor in inductive research: Notes on the Gioia methodology. Organizational Research Methods, 16(1), 15-31.

Green, Judith, \& Thorogood, Nicki. (2013). Qualitative methods for health research: Sage.

Guthrie, James, \& Parker, Lee D. (2016). Whither the accounting profession, accountants and accounting researchers? Commentary and projections. Accounting, Auditing \& Accountability Journal, 29(1), 2-10.

Harry, Beth, Sturges, Keith M, \& Klingner, Janette K. (2005). Mapping the process: An exemplar of process and challenge in grounded theory analysis. Educational researcher, 34(2), 3-13.

Hay, Amanda, \& Samra-Fredericks, Dalvir. (2018). Bringing the heart and soul back in: collaborative inquiry and the DBA. Academy of Management Learning \& Education, amle. 2017.0020.

Haynes, Kathryn. (2017). Accounting as gendering and gendered: A review of 25 years of critical accounting research on gender. Critical Perspectives on Accounting, 43, 110-124. doi: https://doi.org/10.1016/j.cpa.2016.06.004

Heugens, Pursey P. M. A. R., \& Scherer, Andreas Georg. (2010). When Organization Theory Met Business Ethics: Toward Further Symbioses. Business Ethics Quarterly, 20(4), 643-672.

Hoque, Zahirul, Parker, Lee D, Covaleski, Mark A, \& Haynes, Kathryn. (2017). The Routledge Companion to Qualitative Accounting Research Methods: Taylor \& Francis.

Hossain, Monirul Alam, \& Nurunnabi, Mohammad. (2011). Enforcement and compliance of mandatory accounting standards in emerging economies: the case of Pakistan. International Journal of Managerial and Financial Accounting, 3(2), 200-218.

Hughes, Peter. (2010). Decision-making processes in the context of ethical dilemmas: a study of accountants in training. Northumbria University.

Jackling, Beverley, Cooper, Barry J., Leung, Philomena, \& Dellaportas, Steven. (2007). Professional accounting bodies' perceptions of ethical issues, causes of ethical failure and ethics education. Managerial Auditing Journal, 22(9), 928-944. doi: doi:10.1108/02686900710829426

Jackling, Beverley, \& Keneley, Monica. (2009). Influences on the supply of accounting graduates in Australia: a focus on international students. Accounting \& Finance, 49(1), 141-159.

Jones, Michael J. (2011). Creative accounting, fraud and international accounting scandals: John Wiley \& Sons.

Kaur, Amanpreet, \& Lodhia, Sumit. (2018). Stakeholder engagement in sustainability accounting and reporting: A study of Australian local councils. Accounting, Auditing \& Accountability Journal, 31(1), 338-368.

Ken McPhail, Diane Walters. (2009). ACCOUNTING AND BUSINESS ETHICS: An introduction Taylor \& Francis. 
Klein, Gordon. (2015). Ethics in Accounting: A Decision-making Approach: John Wiley \& Sons.

Kotb, Amr, Roberts, Clare, \& Stoner, Greg. (2013). E-business in accounting education in the UK and Ireland: Influences on inclusion in the curriculum. The International Journal of Management Education, 11(3), 150-162. doi: http://dx.doi.org/10.1016/j.ijme.2013.05.002

Lakshmi, Geeta. (2018). Gekko and black swans: Finance theory in UK undergraduate curricula. Critical Perspectives on Accounting.

Langley, Ann. (1999). Strategies for theorizing from process data. Academy of Management review, 24(4), 691-710.

Lawson, Bradley P., Spencer, Angela Wheeler, \& Turek, Monika. (2016). Developments in Ethics Guidelines for CPAs. Journal of Corporate Accounting \& Finance, 27(6), 63-71. doi: 10.1002/jcaf.22190

Lehnert, Kevin, Craft, Jana, Singh, Nitish, \& Park, Yung-Hwal. (2016). The human experience of ethics: a review of a decade of qualitative ethical decision-making research. Business Ethics: A European Review, 25(4), 498-537. doi: 10.1111/beer.12129

Low, Mary, Davey, Howard, \& Hooper, Keith. (2008). Accounting scandals, ethical dilemmas and educational challenges. Critical Perspectives on Accounting, 19(2), 222-254. doi: http://dx.doi.org/10.1016/j.cpa.2006.05.010

Lu, Tao. (2010). A comparative study of business ethics and entrepreneurship in the UK and China. Nottingham Trent University.

Lukmanjaya, Billy. (2019). The role of corporate culture as a contributor to fraud and corruption in Australia: Perceptions of forensic accountants and industry professionals. Queensland University of Technology.

Ma, Zhenzhong. (2009). The status of contemporary business ethics research: Present and future. Journal of Business Ethics, 90, 255-265.

Marzuki, Marzlin, Subramaniam, Nava, Cooper, Barry J., \& Dellaportas, Steven. (2017). Accounting academics' teaching self-efficacy and ethics integration in accounting courses: A Malaysian study. Asian Review of Accounting, 25(1), 148-170. doi: doi:10.1108/ARA-09-2015-0088

Mattessich, Richard. (1994). Archaeology of accounting and Schmandt-Besserat's contribution. Accounting, Business \& Financial History, 4(1), 5-28.

McGuire, Sean T, Omer, Thomas C, \& Sharp, Nathan Y. (2012). The impact of religion on financial reporting irregularities. The Accounting Review, 87(2), 645-673.

Melé, Domènec. (2005). Ethical education in accounting: Integrating rules, values and virtues. Journal of Business Ethics, 57(1), 97-109.

Michaluk, Courtney. (2011). Incorporating ethics into accounting education: A proposal for an undergraduate accounting ethics course for the university of tennessee, knoxville.

Mintz, Steven. (2014). Accounting for the public interest: Springer.

Morales, Jérémy, \& Sponem, Samuel. (2017). You too can have a critical perspective! 25 years of Critical Perspectives on Accounting. Critical Perspectives on Accounting, 43, 149-166. doi: http://doi.org/10.1016/j.cpa.2016.09.003

Mpho, BOSUPENG. (2017). Whistle Blowing: What Do Contemporary Ethical Theories Say? Studies in Business and Economics, 12(1), 19-28.

Mujtaba, Bahaudin G, \& Afza, Talat. (2011). Business ethics perceptions of public and private sector respondents in Pakistan. Far East Journal of Psychology and Business, 3(1), 1-11.

Nikitin, Marc. (2001). The birth of a modern public sector accounting system in France and Britain and the influence of Count Mollien. Accounting History, 6(1), 75-101.

Nisha, Nabila. (2016). Secret reserve accounting: a critical review of Bangladesh. Int. J. Accounting and Finance, 6(4), 255.

O'Leary, Zina. (2004). The essential guide to doing research: Sage.

Onwujekwe, Obinna, Agwu, Prince, Orjiakor, Charles, McKee, Martin, Hutchinson, Eleanor, Mbachu, Chinyere, . . . Ichoku, Hyacinth. (2019). Corruption in Anglophone West Africa health systems: a systematic review of its different variants and the factors that sustain them. Health policy and planning. 
Palea, Vera. (2016). Whither accounting research? A European view. Critical Perspectives on Accounting. doi: http://dx.doi.org/10.1016/j.cpa.2016.03.002

Pan, Peipei, \& Perera, Hector. (2012). Market relevance of university accounting programs: Evidence from Australia. Accounting Forum, 36(2), 91-108. doi: http://dx.doi.org/10.1016/j.accfor.2011.11.001

Parker, Lee D. (2012). Beyond the ticket and the brand: imagining an accounting research future. Accounting \& Finance, 52(4), 1153-1182. doi: 10.1111/j.1467-629X.2012.00507.x

Pine, Kathleen, \& Mazmanian, Melissa. (2016). Artful and contorted coordinating: The ramifications of imposing formal logics of task jurisdiction on situated practice. Academy of Management Journal, amj. 2014.0315.

Point, Sébastien, Fendt, Jacqueline, \& Jonsen, Karsten. (2017). Qualitative Inquiry in Management: Methodological Dilemmas and Concerns in Meta-Analysis. European Management Review, 14(2), 185-204. doi: 10.1111/emre.12097

Rebich, Hannah. (2013). The need for ethics in accounting.

Reiter, Sara Ann. (1996). The Kohlberg-Gilligan controversy: lessons for accounting ethics education. Critical Perspectives on Accounting, 7(1), 33-54.

Rennie, Morina D, Kopp, Lori S, \& Lemon, W Morley. (2014). Auditor-Client Disagreements and Independence: An Exploratory Field Study. Research on Professional Responsibility and Ethics in Accounting, 131-161.

Riccaboni, Angelo, Giovannoni, Elena, Giorgi, Andrea, \& Moscadelli, Stefano. (2006). Accounting and power: evidence from the fourteenth century. Accounting History, 11(1), 41-62.

Rizvi, Shaheer, Tanveer, Muhammad Asif, Saleem, Umer, \& Latif, Moaaz. (2012). BUSINESS STUDENTS'ATTITUDE TOWARDS BUSINESS ETHICS IN PAKISTAN. European Scientific Journal, ESJ, 8(25).

Rosid, Arifin, Evans, Chris, \& Tran-Nam, Binh. (2019). Perceptions of Corruption and Tax NonCompliance Behaviour: Policy Implications for Developing Countries. Available at SSRN 3317994.

Roy, Sandhiya. (2017). The Significance of Business Ethics as a Competency Requirement in Fiji's Accountancy Profession. Australian Academy of Accounting and Finance Review, 2(3), 264-279.

Satava, David, Caldwell, Cam, \& Richards, Linda. (2006). Ethics and the auditing culture: rethinking the foundation of accounting and auditing. Journal of Business Ethics, 64(3), 271-284.

Saud, Shah. (2012). Contribution of Internal Audit in The Achievement of Corporate Goals-How Internal Audit Contribute In Goal Achievements?: A case of Sweden and Pakistan.

Saunders, Mark NK. (2011). Research methods for business students, 5/e: Pearson Education India.

Senate, US. (1976). Subcommittee on Reports, Accounting and Management of the Commission on Government Operations.(Metcalf Committee). The Accounting Establishment: A Staff Study.

Sengupta, Subhanjan, \& Sahay, Arunaditya. (2018). Social enterprises in the Indian context: conceptualizing through qualitative lens. Journal of Global Entrepreneurship Research, 8(1), 1. doi: 10.1186/s40497-018-0087-5

Setó-Pamies, Dolors, \& Papaoikonomou, Eleni. (2016). A Multi-level Perspective for the Integration of Ethics, Corporate Social Responsibility and Sustainability (ECSRS) in Management Education. Journal of Business Ethics, 136(3), 523-538. doi: 10.1007/s10551-014-2535-7

Shahin, Wassim N. (1996). COULD FINANCIAL LIBERALIZATION IGNORE INFORMAL FINANCE? A COMMENTARY / LA LIB\&\#xc9;RALISATION FINANCI\&\#xc8;RE POURRAIT-ELLE IGNORER LES FINANCES STRUCTUR\&\#xc9;ES? UN COMMENTAIRE. Savings and Development, 20(1), 105-116.

Shawver, Tara J., \& Miller, William F. (2017). Moral Intensity Revisited: Measuring the Benefit of Accounting Ethics Interventions. Journal of Business Ethics, 141(3), 587-603. doi: $10.1007 / \mathrm{s} 10551-015-2711-4$

Sikka, Prem. (2009). Financial crisis and the silence of the auditors. Accounting, Organizations and Society, 34(6), 868-873.

Sikka, Prem, \& Lehman, Glen. (2015). The supply-side of corruption and limits to preventing corruption 
within government procurement and constructing ethical subjects. Critical Perspectives on Accounting, 28, 62-70. doi: http://dx.doi.org/10.1016/j.cpa.2015.01.008

Smith, Sarah. (2014). The Effectiveness of Teaching Ethics, and How Different Majors Perceive One Another's Ethics. University of South Florida St. Petersburg.

Solomon, Robert C. (2003). Victims of circumstances? A defense of virtue ethics in business. Business Ethics Quarterly, 13(1), 43-62.

Stoner, Greg. (2011). The perseverance of Pacioli's goods inventory accounting system. Accounting History, 16(3), 313-329.

Suddaby, Roy. (2006). From the editors: What grounded theory is not. Academy of management journal, 49(4), 633-642.

Tormo-Carbó, Guillermina, Seguí-Mas, Elies, \& Oltra, Victor. (2016). Accounting Ethics in Unfriendly Environments: The Educational Challenge. Journal of Business Ethics, 135(1), 161-175. doi: 10.1007/s10551-014-2455-6

Treviño, Linda Klebe, den Nieuwenboer, Niki A., Kreiner, Glen E., \& Bishop, Derron G. (2014). Legitimating the legitimate: A grounded theory study of legitimacy work among Ethics and Compliance Officers. Organizational Behavior and Human Decision Processes, 123(2), 186205. doi: https://doi.org/10.1016/j.obhdp.2013.10.009

Tsang, Eric WK. (1998). A longitudinal study of corporate social reporting in Singapore: The case of the banking, food and beverages and hotel industries. Accounting, Auditing \& Accountability Journal, 11(5), 624-635.

Uyar, Ali, Kuzey, Cemil, Güngörmüs, Ali Haydar, \& Alas, Ruth. (2015). Influence of theory, seniority, and religiosity on the ethical awareness of accountants. Social Responsibility Journal, 11(3), 590-604. doi: doi:10.1108/SRJ-06-2014-0073

Uysal, xd, zg, xfc, xd, \& zmen. (2010). Business Ethics Research with an Accounting Focus: A Bibliometric Analysis from 1988 to 2007. Journal of Business Ethics, 93(1), 137-160.

Vladu, Alina Beattrice, Amat, Oriol, \& Cuzdriorean, Dan Dacian. (2017). Truthfulness in Accounting: How to Discriminate Accounting Manipulators from Non-manipulators. Journal of Business Ethics, 140(4), 633-648. doi: 10.1007/s10551-016-3048-3

Walker, Martin. (2010). Accounting for varieties of capitalism: The case against a single set of global accounting standards. The British Accounting Review, 42(3), 137-152. doi: http://dx.doi.org/10.1016/j.bar.2010.04.003

West, Andrew. (2017). Multinational Tax Avoidance: Virtue Ethics and the Role of Accountants. Journal of Business Ethics, 1-14. doi: 10.1007/s10551-016-3428-8

Williams, Sarah J., \& Adams, Carol A. (2013). Moral accounting? Employee disclosures from a stakeholder accountability perspective. Accounting, Auditing \& Accountability Journal, 26(3), 449-495. doi: doi:10.1108/09513571311311892

Willmott, Hugh. (1986). Organising the profession: a theoretical and historical examination of the development of the major accountancy bodies in the UK. Accounting, Organizations and Society, 11(6), 555-580.

Yamey, Basil S. (2000). The 'particular gain or loss upon each article we deal in': an aspect of mercantile accounting, 1300-1800. Accounting, Business \& Financial History, 10(1), 1-12.

Young, Meredith. (2013). Cultural Influences on Accounting and Its Practices.

Yunis, Mohammad Sohail, Durrani, Laila, \& Khan, Amad. (2017). Corporate Social Responsibility (CSR) in Pakistan: A Critique of the Literature and Future Research Agenda. Business \& Economic Review, 9(1), 65-88.

Zhu, Zheng-guo, \& Zhu, Wen-zhong. (2016). A Historic View of the US Business Ethical Laws and Implications for Developing Countries like China. Review of European Studies, 8(3), 49.

Zubairu, Umaru. (2016). The Impact Of University Education On The Moral Development Of Accounting Students: A Case Study. International Online Journal of Education and Teaching/ISSN: 2148-225X, 3(2), 142-160. 
